\title{
A Nafion-Ceria Composite Membrane Electrolyte for Reduced Methanol Crossover in Direct Methanol Fuel Cells
}

\author{
Parthiban Velayutham ${ }^{1,2}$, Akhila K. Sahu 1,2,* and Sridhar Parthasarathy ${ }^{3, *}$ \\ 1 CSIR - Central Electrochemical Research Institute-Madras Unit, CSIR Madras Complex, Taramani, \\ Chennai 600113, India; sudharshchem@gmail.com \\ 2 Academy of Scientific and Innovative Research (AcSIR), CSIR-Central Electrochemical Research Institute, \\ Karaikudi 630003, India \\ 3 Mesha Energy Solutions Pvt. Ltd., Yeshwanthpur, Bengaluru 560022, India \\ * Correspondence: aksahu@cecri.res.in (A.K.S.); psridhar@meshatech.com (S.P.); Tel.: +91-44-22544554 (A.K.S.) \\ Academic Editor: Francesco Lufrano \\ Received: 7 January 2017; Accepted: 10 February 2017; Published: 21 February 2017
}

\begin{abstract}
An alternative Nafion composite membrane was prepared by incorporating various loadings of $\mathrm{CeO}_{2}$ nanoparticles into the Nafion matrix and evaluated its potential application in direct methanol fuel cells (DMFCs). The effects of $\mathrm{CeO}_{2}$ in the Nafion matrix were systematically studied in terms of surface morphology, thermal and mechanical stability, proton conductivity and methanol permeability. The composite membrane with optimum filler content $\left(1\right.$ wt. $\left.\% \mathrm{CeO}_{2}\right)$ exhibits a proton conductivity of $176 \mathrm{mS} \cdot \mathrm{cm}^{-1}$ at $70{ }^{\circ} \mathrm{C}$, which is about $30 \%$ higher than that of the unmodified membrane. Moreover, all the composite membranes possess a much lower methanol crossover compared to pristine Nafion membrane. In a single cell DMFC test, MEA fabricated with the optimized composite membrane delivered a peak power density of $120 \mathrm{~mW} \cdot \mathrm{cm}^{-2}$ at $70{ }^{\circ} \mathrm{C}$, which is about two times higher in comparison with the pristine Nafion membrane under identical operating conditions.
\end{abstract}

Keywords: polymer electrolyte membrane; ceria; composite membranes; methanol crossover; direct methanol fuel cells

\section{Introduction}

Direct methanol fuel cells (DMFCs) are one of the promising alternative power sources for portable electronics such as laptops or mobile phones owing to their high energy density, low temperature operation, and low / zero emissions [1,2]. Besides, convenient storage of liquid methanol, and no need for auxiliary units such as humidifiers and reformers allows simple and compact DMFC designs. Despite these advantages, methanol crossover across a polymer electrolyte membrane (PEM) from the anode to the cathode compartment in DMFCs limits their wide spread commercial applications [3]. Methanol crossover not only reduces the fuel efficiency, but also poisons the cathode catalyst by direct oxidation of methanol, resulting in a mixed-potential at the cathode compartment [4]. Hence, the issue of methanol crossover needs to be addressed by developing alterative PEM materials to advance the overall performance of DMFCs.

The PEM is a key component in a DMFC which serves as a both a proton conductor and as a separator between the anode and the cathode reactants. Perfluorosulfonic acid membrane materials such as Nafion with first-rate proton conductivity, and high mechanical and thermal stability are being widely used as efficient PEM materials for fuel cells. However, the application of Nafion membranes in DMFCs is limited because of their high methanol permeability. As a result, it is essential to modify the Nafion membrane to meet the PEM requirements for DMFC applications. Generally, this can be done 
by two approaches; (i) composite membranes with hydrophilic organic/inorganic fillers; (ii) surface modification by blending with other polymers [5]. Although the membranes fabricated via surface modification strategies shows a significant reduction in methanol crossover, the drastic reduction in proton conductivity severely affect their performance in fuel cells [6].

To have a balance between proton conductivity and methanol crossover, the composite approach wherein organic/inorganic fillers are incorporated into the Nafion network is believed to be an effective way to prepare the Nafion composite membranes. A major problem associated with this approach is how to obtain a uniform dispersion of the filler materials throughout the polymer matrix and it can be tackled by using nanosized high surface area fillers. Incorporation of nanosized hydrophilic inorganic fillers in the Nafion matrix reduces the methanol crossover by partially blocking the hydrophilic channels along with an improved water uptake and mechanical stability. Many efforts have been focused on the modification of Nafion membranes by incorporation of various inorganic nano fillers into the Nafion matrix to reduce methanol crossover while upholding its proton conductivity [7-11]. Nafion membranes modified with metal oxides such as $\mathrm{TiO}_{2}[12,13], \mathrm{SiO}_{2}[14,15]$, aluminosilicates [3], etc., showed promising results towards the DMFC application. The addition of metal oxides with specific morphological properties select specific sites in the Nafion matrix and increase the interaction between polymer matrix and filler materials resulting in superior Nafion composite membranes [16]. Moreover, the hygroscopic nature of metal oxides improves the water retention properties of the resulting membranes. Consequently, many efforts have also been focused on the modification of Nafion membranes by nanofillers such as graphene [11], graphene oxides [9] and inorganic polysiloxane [17], and superior proton conductivity behavior of the resulting composite membranes, with efficient reduction in methanol crossover, has been demonstrated.

Cerium oxide, a rare-earth metal oxide with good hygroscopic properties was also explored as a potential filler material for Nafion in constituting a composite membrane [18,19]. Trogadas et al. studied the effect of incorporating cerium oxide nanoparticles into a Nafion membrane for PEM fuel cells and found that the addition of ceria to the PEM lowered the macroscopic degradation rate by over one order of magnitude without altering the proton conductivity [18]. Weissbach et al. prepared a Nafion- $\mathrm{CeO}_{2}$ composite membrane and showed that the composite membrane exhibited higher stability with improved water uptake capacity compared to a bare Nafion membrane [19]. However, a detailed study on mitigating methanol crossover and direct performance evaluation of these membranes in the DMFC is lacking.

The present study focused on the preparation of an alternate Nafion composite membrane by incorporating nanosized cerium dioxide filler into a Nafion polymer matrix. The effect of ceria nanoparticles and optimization of the filler content in the composite membrane were examined in terms of methanol crossover, water uptake, proton conductivity, and thermal and mechanical stability along with DMFC performance evaluation. A DMFC comprising the proposed Nafion-CeO $\mathrm{C}_{2}(1 \%)$ composite membrane delivers a peak power density of $120 \mathrm{~mW} \cdot \mathrm{cm}^{-2}$ at $70{ }^{\circ} \mathrm{C}$ and ambient pressure and greatly suppresses the methanol permeability of about $40 \%$ in relation to the pristine Nafion membrane.

\section{Experimental}

\subsection{Materials}

Nafion ionomer of $5 \mathrm{wt}$ \% was procured from DuPont (Wilmington, DE, USA). Nanosized cerium dioxide $\left(\mathrm{CeO}_{2}, 99.9 \%\right)$ was procured from Acros Organics (Mumbai, India). The Pt/C (40 wt. \%) and $\mathrm{Pt}-\mathrm{Ru} / \mathrm{C}(40 \mathrm{wt} . \% \mathrm{Pt}$ and $20 \mathrm{wt}$. \% Ru) catalysts were obtained from Alfa Aesar (Johnson Matthey) Ltd. (Heysham, UK). Gas diffusion layers (GDL); Sigracet DC-35) were obtained from the SGL Group (Wiesbaden, Germany). All the chemicals were used as received. De-ionized water $(18 \mathrm{~m} \Omega)$ was used throughout the study. 


\subsection{Preparation of Pristine Nafion and Nafion- $\mathrm{CeO}_{2}$ Composite Membranes}

The desired amount of $\mathrm{CeO}_{2}$ nanoparticles was added into a $5 \mathrm{wt}$. \% Nafion ionomer solution and mixed thoroughly in an ultrasonic bath for $1 \mathrm{~h}$, followed by mechanical stirring for $12 \mathrm{~h}$. The resulting admixture was then poured into a flat glass Petri dish and dried at $80^{\circ} \mathrm{C}$ for $6 \mathrm{~h}$. The composite membrane thus formed was removed by adding water. Before any further analysis, all the membranes were pre-treated with $0.5 \mathrm{M}$ sulfuric acid $\left(\mathrm{H}_{2} \mathrm{SO}_{4}\right)$ at $80^{\circ} \mathrm{C}$ for $1 \mathrm{~h}$ followed by washing with de-ionized water until the $\mathrm{pH}$ of the washing water reaches neutral. The thickness of all the composite membranes was measured using a digital micrometer and was found to be $\sim 160 \mu \mathrm{m}$. Pristine Nafion membrane of identical thickness was also prepared without any filler content for comparison.

\subsection{Physicochemical Characterization}

Cerium dioxide was characterized by powder X-ray diffraction (XRD) to identify the phases and to determine the crystallite size. XRD patterns were recorded on a Pan Analytical X-ray diffractometer (Philips, Coventry, UK) using Cu-K $\alpha\left(\lambda=1.54 \AA\right.$ ) radiation. The scanning angle $2 \theta$ was between $5^{\circ}$ and $80^{\circ}$ with a step size $0.02^{\circ}$. The surface morphology and corresponding quantitative elemental mappings of pristine Nafion and Nafion- $\mathrm{CeO}_{2}$ composite membrane was examined in a Field Emission Scanning Electron Microscope (MIRA3, TESCAN, Brno, Czech Republic) equipped with an energy dispersive X-ray (EDX) spectrometer. Morphological differences between the Nafion- $\mathrm{CeO}_{2}$ composite membranes in comparison with pristine recast Nafion was observed by atomic force microscopy (AFM; Pico SPM-Picoscan 2100, Molecular Imaging, Arizona, AZ, USA). The thermal stability of Nafion-CeO composite membranes were studied using a STA 449 TG-DSC instrument (NETZSCH, Bavaria, Germany) in the temperature range between 30 and $800{ }^{\circ} \mathrm{C}$ at a heating rate of $5{ }^{\circ} \mathrm{C} \cdot \mathrm{min}^{-1}$ under nitrogen atmosphere. The mechanical strength for pristine Nafion and optimized composite membrane was evaluated from the stress-strain test on a Universal Testing Maching (UTM; H5KT-10066 US, Tinius Olsen Testing Machine Co., Horsham, PA, USA) at $30^{\circ} \mathrm{C}$.

\subsection{Proton Conductivity}

The in-plane proton conductivity of membranes was measured by a four-probe electrochemical impedance spectroscopy (EIS) method using a membrane conductivity cell (BT-112, Bekktech, Southern pines, NC, USA) at different temperatures [20]. The membrane samples with area of $1.5 \mathrm{~cm} \times 2.5 \mathrm{~cm}$ were assembled in the cell in contact with four platinum electrodes placed at fixed positions. The potentiostat (SP-150, Biologic, Seyssinet-Pariset, France) was set to apply the frequency range between $1 \mathrm{MHz}$ and $1 \mathrm{~Hz}$ and the ac impedance spectra was recorded with amplitude of $10 \mathrm{mV}$. The temperature and the humidity were controlled by a humidity chamber (SH-242, Espec, Hudsonville, MI, USA) and the samples were equilibrated for at least $30 \mathrm{~min}$ at requisite temperature and humidity conditions before the measurements. The resistance value associated with membrane conductivity was determined from the high frequency intercept of the impedance with the real axis. Proton conductivity was calculated using the measured resistance according to following equation:

$$
\sigma=\frac{L}{R \times W \times T}
$$

where, $\sigma$ is the proton conductivity of the membrane in $\mathrm{S} \cdot \mathrm{cm}^{-1} ; L=0.425 \mathrm{~cm}$, the fixed distance between two Pt electrodes; $R$ is the membrane resistance in $\Omega ; W$ is the width of the sample in $\mathrm{cm}$; and $T$ is the thickness of the membrane in $\mathrm{cm}$.

\subsection{Water Uptake and Ion-Exchange Capacity of the Membranes}

The water uptake capacity of the pristine and Nafion composite membranes was measured by measuring the weight difference between the dry and wet membranes. Membrane samples were first dried at $80^{\circ} \mathrm{C}$ for $6 \mathrm{~h}$ and weight of the dried samples was recorded. The dried membrane sample 
was soaked in a glass container filled with de-ionized water at room temperature for $24 \mathrm{~h}$. Then, the membrane sample was removed from water and excess surface water was quickly wiped off with tissue paper and the sample reweighed immediately. By using the wet and dry weight of the membrane samples, the water uptake was calculated from Equation (2):

$$
\text { Water uptake }(\%)=\frac{\mathrm{W}_{\mathrm{w}}-\mathrm{W}_{\mathrm{d}}}{\mathrm{W}_{\mathrm{d}}} \times 100
$$

where, $\mathrm{W}_{\mathrm{d}}$ and $\mathrm{W}_{\mathrm{w}}$ are the weight of dry and wet membranes, respectively.

Ion-exchange Capacity (IEC) is defined as the quantity of accessible sulfonic acid groups for proton exchange (in moles) per gram of polymer sample. The IEC of each sample was measured by the acid-base titration method [21]. A membrane sample $(0.5 \mathrm{~g})$ was soaked in $3 \mathrm{~N} \mathrm{NaCl}(30 \mathrm{~mL})$ for $24 \mathrm{~h}$. To measure displaced $\mathrm{H}^{+}$ions in sample, a known volume of $\mathrm{NaCl}$ solution was titrated against $0.01 \mathrm{~N} \mathrm{NaOH}$ solution using phenolphthalein as an indicator. IEC of the sample was calculated using the following equation:

$$
\text { IEC }=\frac{\text { Volume of } \mathrm{NaOH} \text { consumed } \times \text { Molarity of } \mathrm{NaOH}}{\text { Weight of the dried sample }} \mathrm{mmol} / \mathrm{g}
$$

\subsection{Fabrication of the Membrane Electrode Assemblies (MEAs) and Fuel Cell Performance Evaluation}

Catalyst slurry for the anode and the cathode catalyst layer was prepared by mixing the Pt-Ru/C (Pt-40 wt. \% and Ru-20 wt. \%) or 40 wt. \% Pt/C catalyst with 5 wt. \% Nafion ionomer and isopropyl alcohol. To constitute the anode and the cathode electrodes, the homogeneous catalyst slurries were applied on the GDL until a $2 \mathrm{mg} \cdot \mathrm{cm}^{-2}$ metal loading is obtained. The MEAs were fabricated by hot pressing the pre-treated membranes sandwiched between the anode and cathode electrodes at $130{ }^{\circ} \mathrm{C}$ under $10 \mathrm{~kg} \cdot \mathrm{cm}^{-2}$ for $3 \mathrm{~min}$.

The DMFC performances of the MEAs were evaluated in a standard $4 \mathrm{~cm}^{2}$ fuel cell test fixture procured from Fuel Cell Technologies Inc. (Albuquerque, NM, USA). 2 M aqueous methanol solution and oxygen were supplied on the anode and cathode inlet of the DMFC, respectively. The flow rates of methanol and oxygen were $2 \mathrm{~mL} \cdot \mathrm{min}^{-1}$ and $250 \mathrm{~mL} \cdot \mathrm{min}^{-1}$. The DMFC performance of pristine Nafion and Nafion- $\mathrm{CeO}_{2}$ composite membranes with different filler content were evaluated at $70{ }^{\circ} \mathrm{C}$ under ambient pressure.

\subsection{Methanol Permeability Measurements}

Methanol permeability measurements was performed by the linear sweep voltammetry (LSV) technique in cell mode using a potentiostat (PGSTAT 30, Autolab, Utrecht, The Netherlands) in the voltage range from 0 and $1.0 \mathrm{~V}$ at the scan rate of $5 \mathrm{mV} \cdot \mathrm{s}^{-1}$ [22]. Single cells with the active area of $4 \mathrm{~cm}^{2}$ were assembled and conditioned at open circuit voltage (OCV) for $1 \mathrm{~h}$ at $70{ }^{\circ} \mathrm{C}$. During measurements, oxygen on the cathode side was replaced by nitrogen at a flow rate of $100 \mathrm{~mL} \cdot \mathrm{min}^{-1}$ and the methanol was passed on the anode side at a flow rate of $2 \mathrm{~mL} \cdot \mathrm{min}^{-1}$ at room temperature. The cathode of the cell was served as working electrode and anode of the cell was served as counter and reference electrodes of the potentiostat. The current known as methanol cross-over current that was measured from the cell corresponded to the oxidation of diffused methanol, which reached a plateau when all the methanol was converted to $\mathrm{CO}_{2}$ under steady state conditions [1].

\section{Results and Discussion}

As received $\mathrm{CeO}_{2}$ powder was characterized by its powder X-ray diffraction pattern and FE-SEM for better understanding of its crystalline phases and surface morphology. Figure 1a shows the XRD pattern which displays diffraction peaks at $2 \theta$ of $28.55^{\circ}, 33.08^{\circ}, 47.49^{\circ}, 56.34^{\circ}, 59.10^{\circ}, 69.42^{\circ}, 76.70^{\circ}$, and $79.08^{\circ}$ and correspond to the (111), (200), (220), (311), (222), (400), (331) and (420) planes of $\mathrm{CeO}_{2}$, respectively. In addition, the XRD pattern revealed the cubic structure of $\mathrm{CeO}_{2}$ with $\mathrm{Fm}-3 \mathrm{~m}$ space 
group (COD 9009008). The obtained XRD patterns for $\mathrm{CeO}_{2}$ are in good agreement with the literature reports $[23,24]$. By using the Scherrer formula, the crystallite size of $\mathrm{CeO}_{2}$ was calculated from the (111) diffraction and it is found to be $52.62 \mathrm{~nm}$. The morphology of $\mathrm{CeO}_{2}$ was analyzed by FE-SEM and the corresponding images are presented in Figure $1 \mathrm{~b}$. It can be seen that the $\mathrm{CeO}_{2}$ exhibits a cubic-like morphology. The incorporation of this nanosize $\mathrm{CeO}_{2}$ in the Nafion matrix resulted in a uniform distribution.

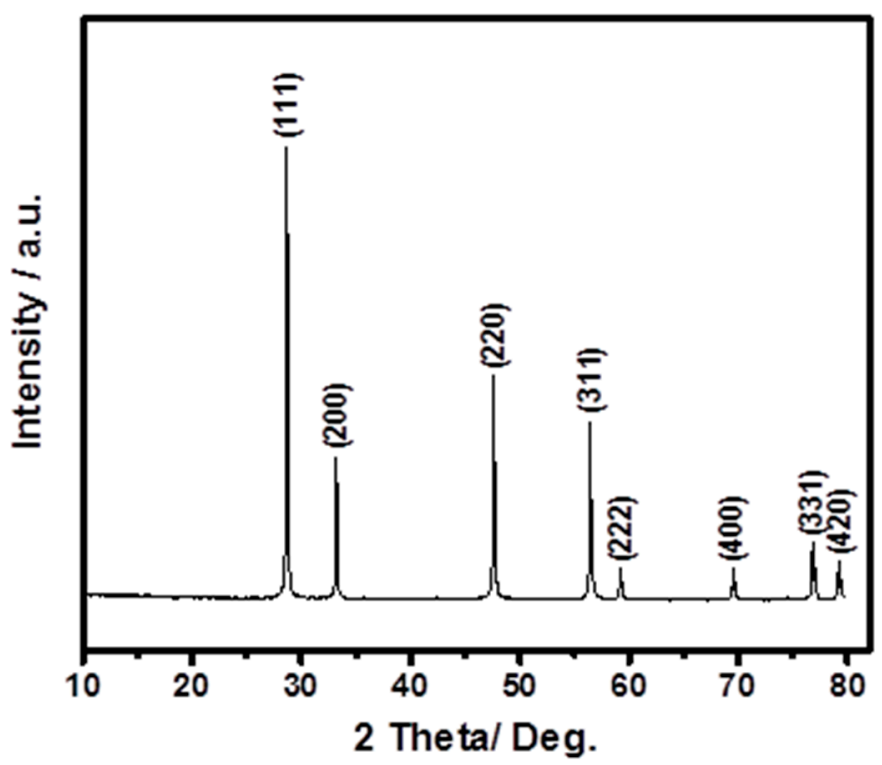

(a)

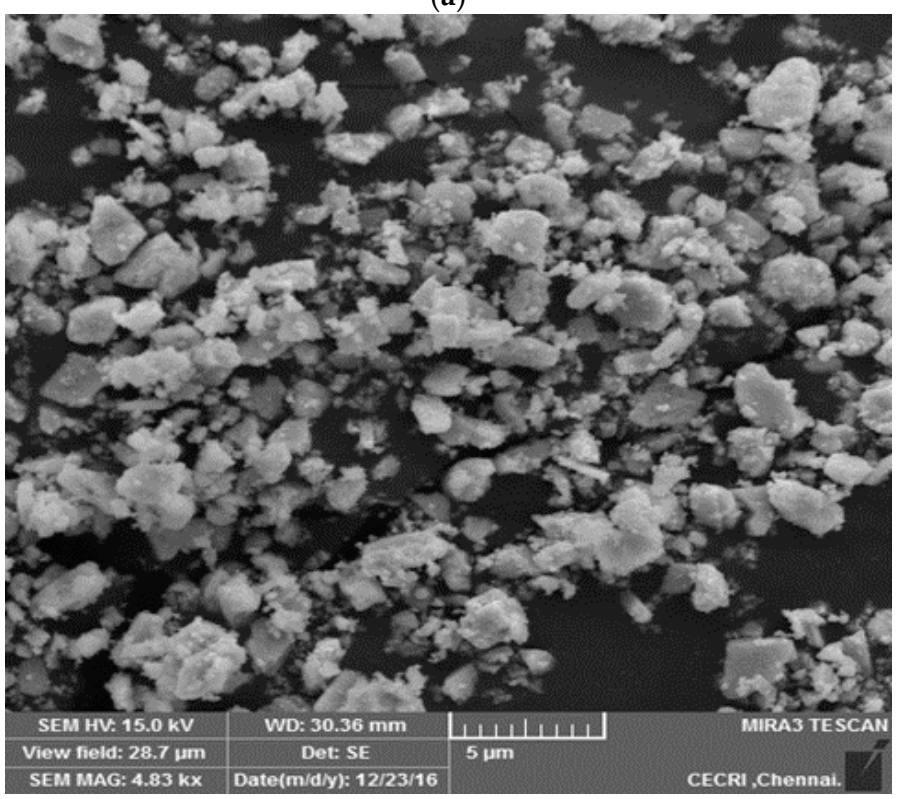

(b)

Figure 1. X-ray diffraction pattern (a) and FE-SEM image (b) of $\mathrm{CeO}_{2}$ nanoparticles.

The surface morphology of recast pristine Nafion membrane and Nafion- $\mathrm{CeO}_{2}$ composite membrane were investigated by FE-SEM analysis and the corresponding images are shown in Figure 2 . It can be seen that the pristine Nafion membrane has a relatively neat and smooth surface (Figure 2a). Cerium dioxide fillers dispersed homogeneously throughout the Nafion matrix and increased the surface roughness in case of composite membrane, as shown in Figure 2b. The EDX elemental analyses for pristine Nafion and Nafion- $\mathrm{CeO}_{2}$ composite membranes are shown in Figure 2f,g respectively. 
The existence of three peaks for $\mathrm{Ce}$ and the increased intensity of the $\mathrm{O}$ peak in the EDX spectrum of the composite membrane (Figure $2 \mathrm{~g}$ ) confirm the presence of $\mathrm{CeO}_{2}$ nanoparticles in the Nafion matrix. The density and distribution of $\mathrm{C}, \mathrm{O}$ and $\mathrm{Ce}$ in the composite membrane is mapped as shown in (Figure 2c-e). The selected area used for mapping is shown in the square box in Figure 2b. It can be seen that the elemental $\mathrm{Ce}$ of ceria nanoparticles is distributed homogeneously on the entire surface of the Nafion- $\mathrm{CeO}_{2}$ composite membrane. Further, the $\mathrm{O}$ content is denser in the case of Nafion-CeO composite membrane compared to the pristine Nafion membrane.
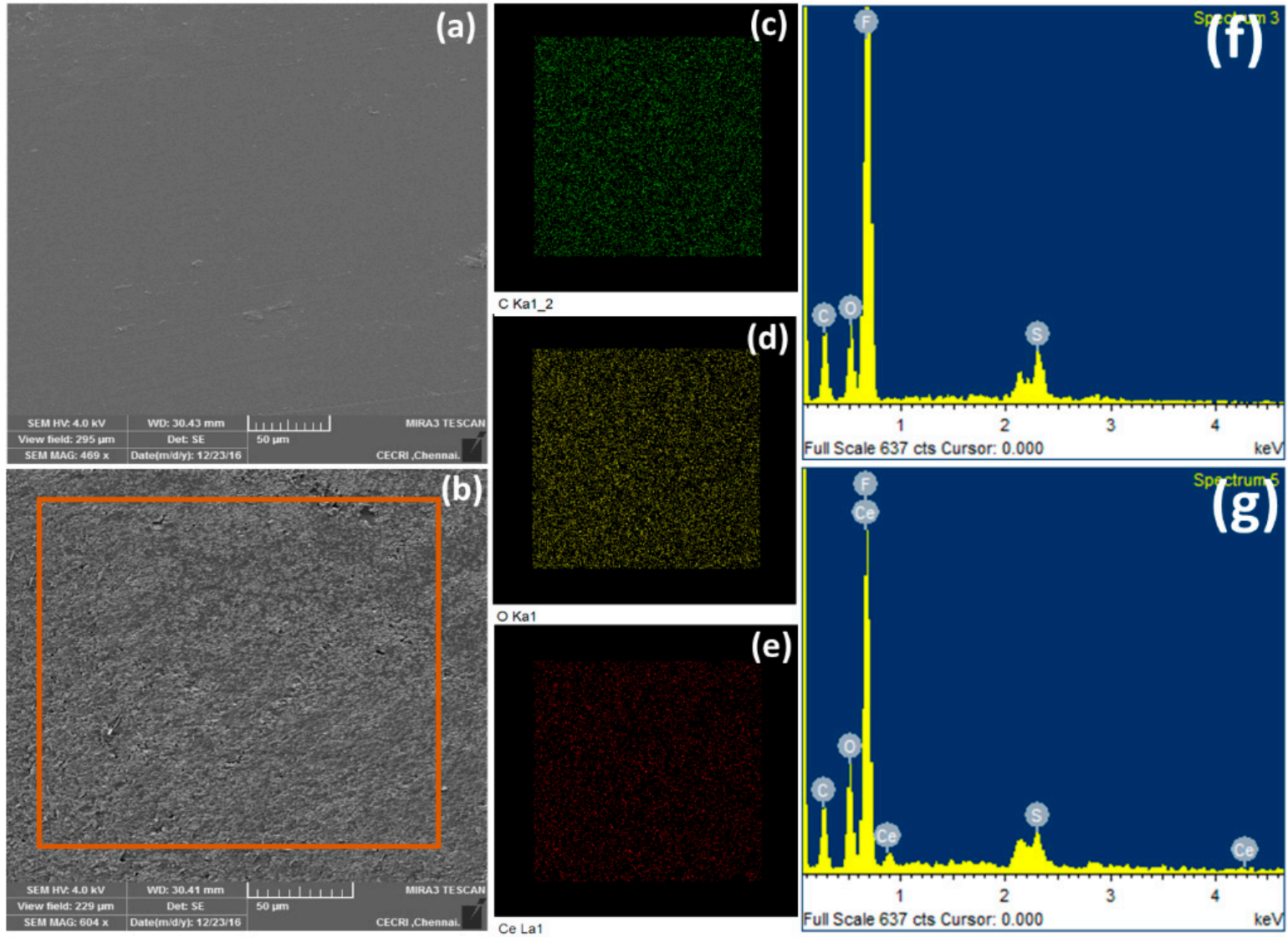

Figure 2. FE-SEM images of pristine Nafion (a) and $\mathrm{Nafion}-\mathrm{CeO}_{2}(1 \mathrm{wt}$. \%) composite membrane (b); Corresponding quantitative EDX elemental mappings for carbon (c), oxygen (d), ceria (e) for Nafion- $\mathrm{CeO}_{2}$ (1 wt. \%) composite membrane (quantitative EDX elemental mapping performed on a particular area is marked in Figure 2b); EDX spectra of pristine Nafion (f) and Nafion-CeO 2 (1 wt. \%) composite membrane $(\mathbf{g})$.

Deeper understanding of the interaction between fillers with Nafion matrix and the related morphological changes was obtained from AFM images as shown in Figure 3. The images were recorded for a scan area of $10 \mu \mathrm{m} \times 10 \mu \mathrm{m}$. As seen in topography image, the pristine Nafion possesses narrowed hydrophilic channels with smooth surfaces. On the other hand, the added $\mathrm{CeO}_{2}$ nanoparticles effectively cover the hydrophilic channels causing increased surface roughness in the composite membranes. From the topography and phase images, we can clearly see significant changes in the surface morphology with the addition of $\mathrm{CeO}_{2}$, which indicates the strong interaction of filler material with the Nafion matrix. Figure 3e,f present the surface roughness analysis of the pristine and composite membranes. The root mean square (RMS) roughness values of $16.3 \mathrm{~nm}$ and $25.2 \mathrm{~nm}$ obtained for pristine and composite membranes, respectively, indicate an increase in the surface roughness in the case of composite membrane due to the presence of $\mathrm{CeO}_{2}$ nanoparticles. The increased roughness 
for Nafion composite membranes is highly beneficial to improve the contact between the electrodes and membrane.
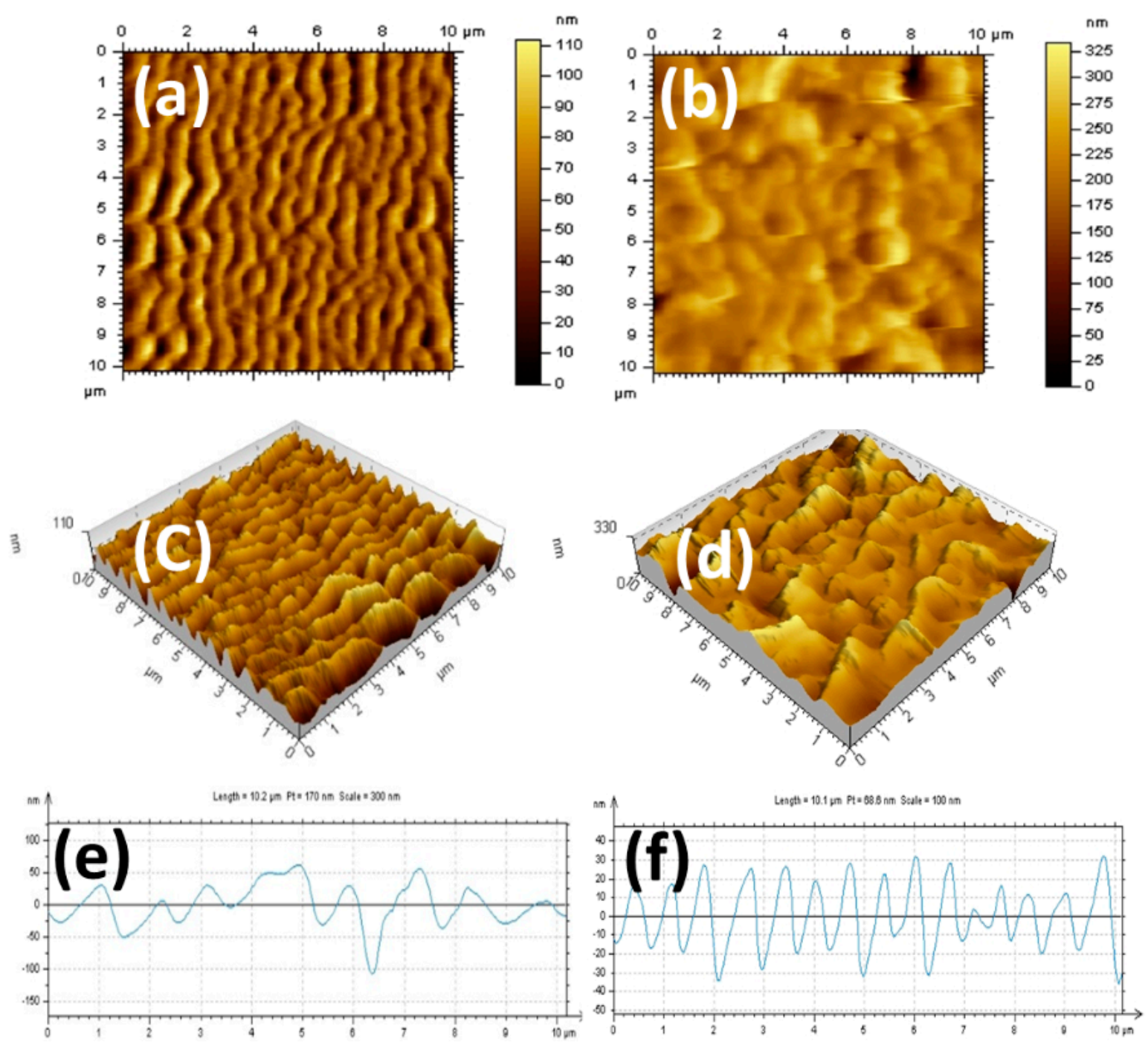

Figure 3. (a) Topography of pristine Nafion membrane; (b) Topography of Nafion- $\mathrm{CeO}_{2}(1 \mathrm{wt}$ \% $)$ composite membrane; (c) Phase image of pristine Nafion membrane; (d) Phase image of Nafion- $-\mathrm{CeO}_{2}$ (1 wt. \%) composite membrane; (e) Line profile of pristine Nafion membrane; (f) Line profile of Nafion- $\mathrm{CeO}_{2}(1 \mathrm{wt}$ \%) composite membrane.

TGA curves of the pristine Nafion and Nafion- $\mathrm{CeO}_{2}$ composite membranes are compared in Figure $4 \mathrm{a}$, wherein a typical three stage weight loss is observed for all the membranes. The primary weight loss at the temperature range between 30 and $200{ }^{\circ} \mathrm{C}$ is related to the loss of surface and bound water molecules. The second weight loss region between 200 and $400{ }^{\circ} \mathrm{C}$ corresponds to the degradation of ion-exchange functionalities from the side chains. No significant weight loss change was observed for both pristine and composite membranes up to this temperature range. The final weight loss between 400 and $500{ }^{\circ} \mathrm{C}$ is attributed to the degradation of the main chain (i.e., the Teflon backbone) of the Nafion membrane. The composite membranes showed a better stability at this temperature compared to pristine Nafion. This can be attributed to the presence of the ceramic fillers and their close interaction with the hydrophobic Nafion backbones [25]. The thermal degradation of pristine Nafion membrane concurs with the literature reports [26] and all the membranes retain up to $90 \%$ of their original weight until $300{ }^{\circ} \mathrm{C}$ in which the fuel cell operating temperature falls. The tensile 
strength of optimized Nafion- $\mathrm{CeO}_{2}(1 \mathrm{wt}$. \%) composite membrane and pristine Nafion membrane are shown in Figure $4 \mathrm{~b}$. Even though the composite membrane exhibits a lower elongation, the Young's modulus (calculated by dividing stress by strain) for the composite membrane is $130 \mathrm{MPa}$, which is much higher than that of pristine Nafion membrane (71 MPa).
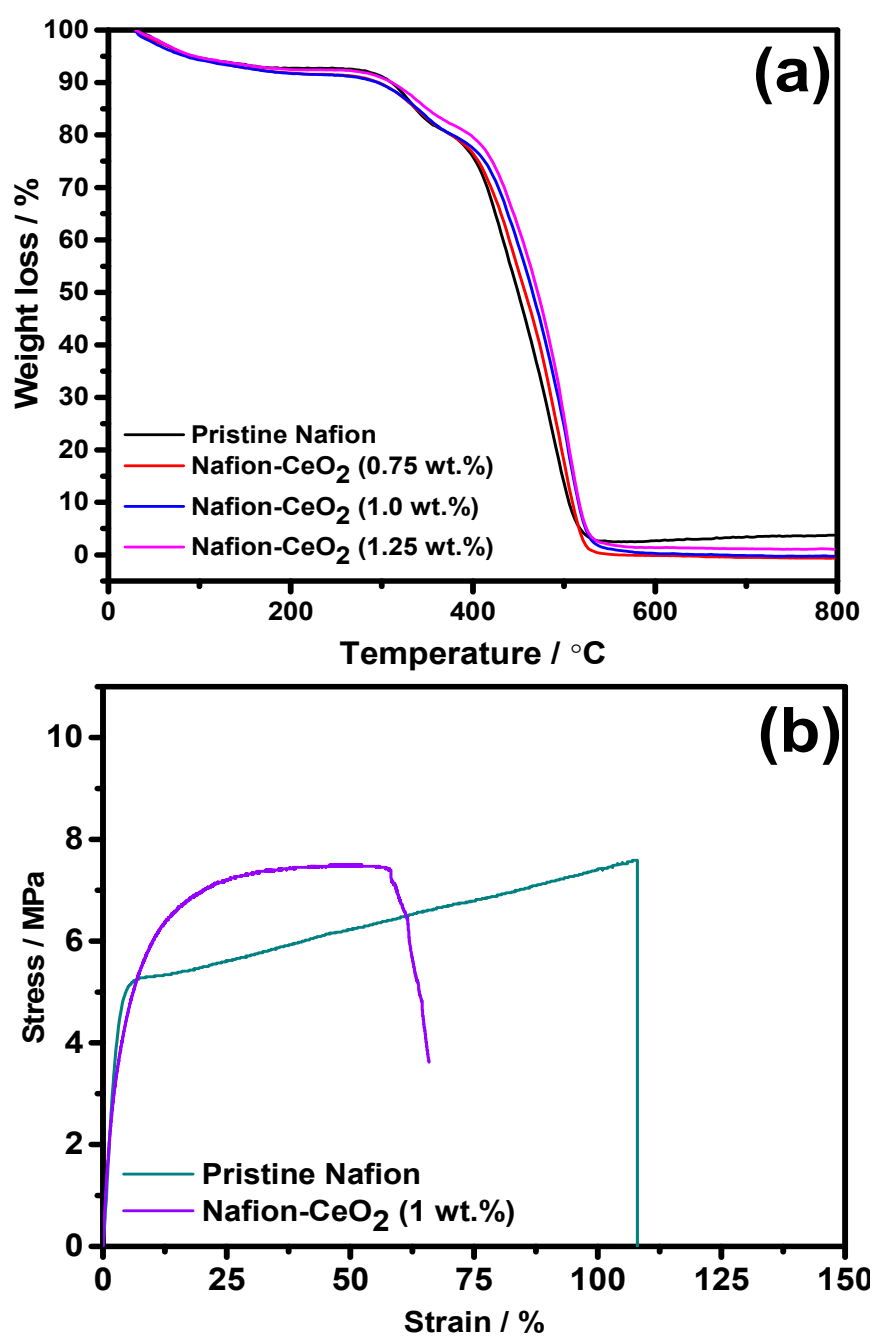

Figure 4. (a) Thermogravimetric analysis of pristine $\mathrm{Nafion}$ and $\mathrm{Nafion}-\mathrm{CeO}_{2}$ composite membrane;

(b) Tensile strength of pristine Nafion and Nafion- $\mathrm{CeO}_{2}$ (1 wt. \%) composite membrane.

Water uptake and ion-exchange capacity have a strong influence on the proton conductivity of a PEM. The water molecules present in a PEM play a vital role in the proton conduction via both the vehicular and Grotthuss mechanisms. The water uptake and IEC values of pristine Nafion and Nafion- $\mathrm{CeO}_{2}$ composite membranes are listed in Table 1.

From the table, the water uptake capacity of the composite membranes considerably increased upon addition of $\mathrm{CeO}_{2}$ nanoparticles compared to pristine Nafion membrane. The water uptake capacity of composite membrane with $1 \mathrm{wt}$. \% filler content is about $25.9 \%$ as compared to $18.3 \%$ for pristine membrane. The increase in water uptake capacity of the composite membranes can be attributed to the hygroscopic nature of $\mathrm{CeO}_{2}$ nanoparticles and their uniform distribution over the polymer matrix. However, the water uptake decreased when the content of $\mathrm{CeO}_{2}$ is more than $1 \mathrm{wt} . \%$, probably due to the aggregation of oxide filler in the composite membrane [27]. 
Table 1. Water uptake capacity, Ion-exchange capacity, proton conductivity, peak power density, methanol crossover current density of pristine Nafion and $\mathrm{Nafion}-\mathrm{CeO}_{2} \mathrm{Composite}$ membranes.

\begin{tabular}{ccccccc}
\hline S1.No. & $\begin{array}{c}\text { Membrane } \\
\text { Types }\end{array}$ & $\begin{array}{c}\text { Water } \\
\text { Uptake (\%) }\end{array}$ & $\begin{array}{c}\text { Ion-Exchange } \\
\text { Capacity } \\
\left(\mathbf{m} \cdot \mathbf{m o l} \cdot \mathbf{g}^{-1}\right)\end{array}$ & $\begin{array}{c}\text { Proton } \\
\text { Conductivity } \\
\left(\mathbf{m S} \cdot \mathbf{c m}^{-1}\right) \\
\text { at 70 }{ }^{\circ} \mathbf{C}\end{array}$ & $\begin{array}{c}\text { Peak Power } \\
\text { Density } \\
\left(\mathbf{m W} \cdot \mathbf{c m}^{-2}\right)\end{array}$ & $\begin{array}{c}\text { Methanol Crossover Current } \\
\text { Density }\left(\mathbf{m A} \cdot \mathbf{c m}^{-2}\right) \text { at } \\
\text { Room Temp. }\end{array}$ \\
\hline 1 & $\begin{array}{c}\text { Pristine } \\
\text { Nafion }\end{array}$ & $18.3 \pm 0.3$ & $0.91 \pm 0.01$ & 136 & 63 & 181 \\
\hline 2 & $\begin{array}{c}\text { Nafion-CeO } \\
(0.75 \text { wt. \%) }\end{array}$ & $22.2 \pm 0.3$ & $0.87 \pm 0.01$ & 152 & 78 & 158 \\
\hline 3 & $\begin{array}{c}\text { Nafion-CeO } \\
(1.0 \text { wt. \%) }\end{array}$ & $25.9 \pm 0.3$ & $0.84 \pm 0.01$ & 176 & 120 & 106 \\
\hline 4 & $\begin{array}{c}\text { Nafion-CeO } \\
(1.25 \text { wt. \%) }\end{array}$ & $24.0 \pm 0.3$ & $0.82 \pm 0.01$ & 165 & 99 & 121 \\
\hline
\end{tabular}

IEC, which measures the density of proton exchangeable groups present in the membrane, is an important parameter. The IECs of pristine Nafion and $\mathrm{Nafion}-\mathrm{CeO}_{2}$ composite membranes was measured and are summarized in Table 1 . The IEC of pristine Nafion is about $0.91 \mathrm{~m} \cdot \mathrm{mol} \cdot \mathrm{g}^{-1}$, and the IEC value of all the composite membranes was slightly lower. The decrease in the IEC value of composite membrane is mainly due to the addition of $\mathrm{CeO}_{2}$ nanoparticles with no proton dissociation ability and a trivial ionic aggregation in the Nafion- $\mathrm{CeO}_{2}$ composite matrix.

Besides the filler content in the composite membrane, the size, shape and dispersion of filler particles play a major role and are the deciding factors in determining membrane compatibility, proton conductivity, methanol permeability, etc. [28]. The addition of nanofillers to the Nafion matrix without any phase separation increases the proton conductivity due to the higher water uptake capacity and hinders the methanol transport across the membrane. The proton conductivity of pristine Nafion and Nafion- $\mathrm{CeO}_{2}$ composite membrane as a function of temperature under fully humidified conditions is shown in Figure 5. The proton conductivity of all the membranes gradually increased as the temperature increased up to $90{ }^{\circ} \mathrm{C}$, and started to decline at $100{ }^{\circ} \mathrm{C}$ due to the non-availability of adequate water molecules. At all the temperatures, Nafion- $\mathrm{CeO}_{2}$ composite membranes showed superior proton conductivity compared to pristine Nafion membrane. The measured proton conductivity for the pristine Nafion membrane and Nafion composite membrane with $1 \mathrm{wt} . \% \mathrm{CeO}_{2}$ content at $70{ }^{\circ} \mathrm{C}$ is $136 \mathrm{mS} \cdot \mathrm{cm}^{-1}$ and $176 \mathrm{mS} \cdot \mathrm{cm}^{-1}$, respectively. The increase in the proton conductivity of about $30 \%$ for the composite membranes is mainly due to their higher water uptake capacity with specific orientation and interaction of fillers with the polymer. The bulk water molecules present in the membrane act as charge carriers according to the vehicular mechanism [29]. Thus, the proton conductivity appreciably increased for the composite membrane developed in this study as a result of superior vehicular mechanism although there is small decline in the IEC. Nevertheless, conductivity slightly decreased for the $\mathrm{Nafion}-\mathrm{CeO}_{2}$ composite membrane with the filler content of above $1 \mathrm{wt}$. \% because of its lower water uptake and sensible interruption in the proton conducting channels of the Nafion.

In DMFC, methanol crossover is a critical factor which is responsible for about a $30 \%$ performance reduction as methanol crossover results in cathode catalyst poisoning and low fuel efficiency. Nafion possesses high methanol permeability because of its widened hydrophilic channels, and partially blocking these channels will significantly reduce the crossover. In the composite approach, the extent of methanol crossover largely depends on the distribution of fillers and their effective interaction with the polymer matrix [30]. The uniform distribution of added fillers in Nafion membranes reduces the size of channels that are available for methanol passage whereas immense agglomeration has a negative impact on methanol crossover. The methanol crossover limiting current densities of pristine Nafion and Nafion- $\mathrm{CeO}_{2}$ composite membranes were measured electrochemically and the results are shown in Figure 6. It can be clearly seen that the methanol crossover decreases after modification of the 
Nafion membrane with $\mathrm{CeO}_{2}$ nanoparticles. A limiting current density of $106 \mathrm{~mA} \cdot \mathrm{cm}^{-2}$ is obtained for the single cell assembled with $1.25 \mathrm{wt}$. \% $\mathrm{CeO}_{2}-\mathrm{Nafion}$ composite membrane, which is about $40 \%$ lower than that of pristine Nafion membrane $\left(181 \mathrm{~mA} \cdot \mathrm{cm}^{-2}\right)$. The decrease in methanol crossover can be understood from the FE-SEM surface morphology of Nafion- $\mathrm{CeO}_{2}$ composite membrane where the $\mathrm{CeO}_{2}$ nanoparticles are uniformly distributed in the Nafion matrix.

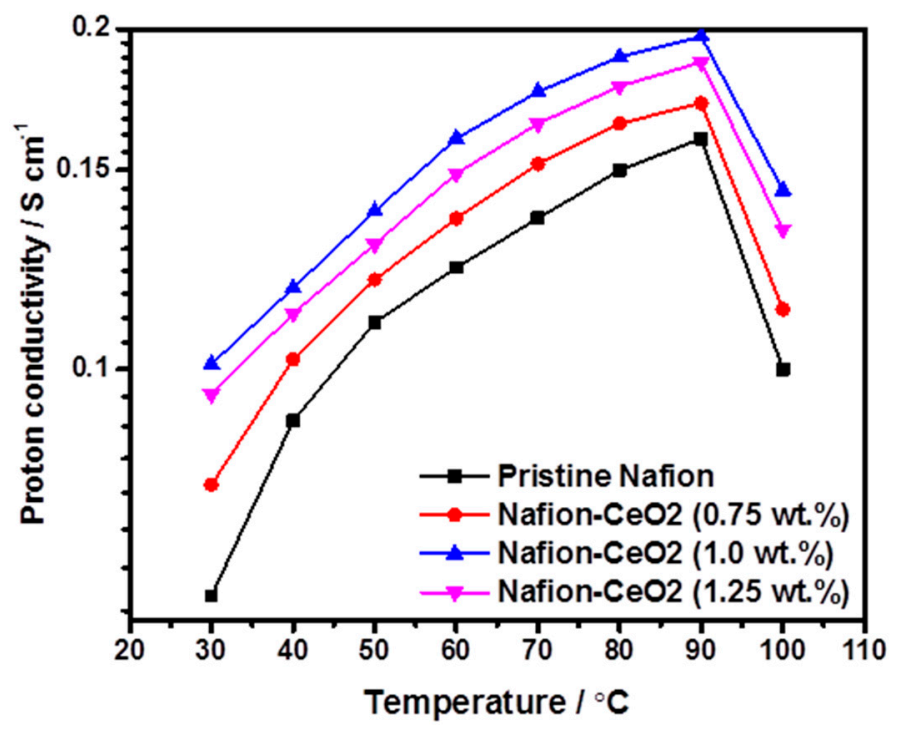

Figure 5. Proton conductivity of pristine Nafion and Nafion- $\mathrm{CeO}_{2}$ composite membranes at different temperatures under $100 \% \mathrm{RH}$.

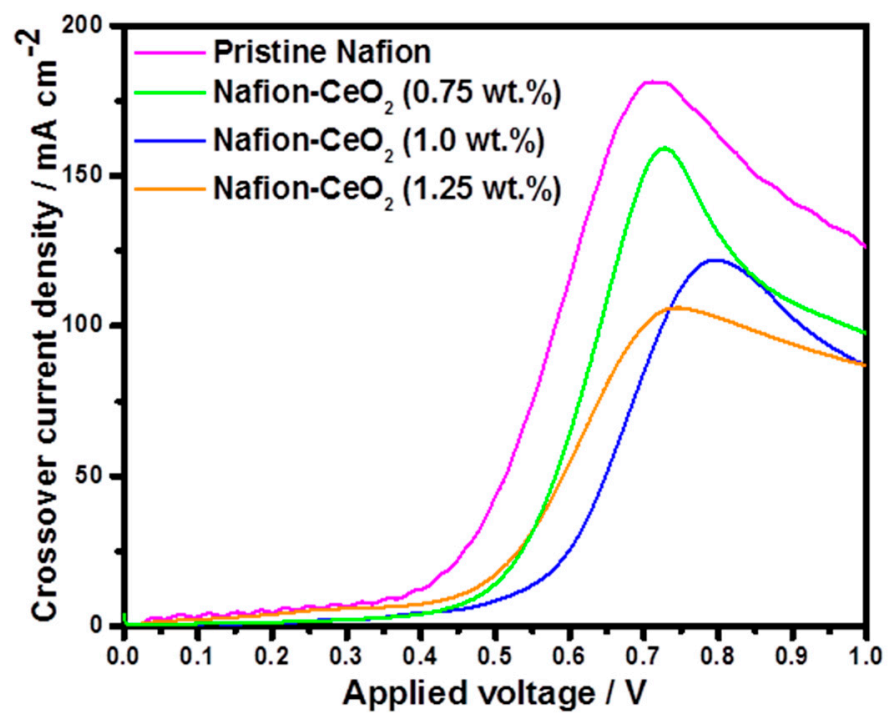

Figure 6. Methanol crossover current densities of pristine Nafion and Nafion- $\mathrm{CeO}_{2}$ composite membranes at room temperature.

The application of composite membranes developed in this study was evaluated in a DMFC single cell at $70{ }^{\circ} \mathrm{C}$ under ambient pressure. Comparative polarization curves and power densities of pristine Nafion and Nafion- $\mathrm{CeO}_{2}$ composite membranes are shown in Figure 7a. The pristine Nafion membrane showed a high polarization loss and low peak power density due to the high methanol crossover and low proton conductivity. In contrast, $\mathrm{MEAs}$ fabricated with the Nafion-CeO composite membranes exhibited higher peak power densities compared to pristine Nafion membrane. Among the composite membranes, Nafion- $\mathrm{CeO}_{2}$ composite membrane with $1 \mathrm{wt}$. \% filler content 
possesses a peak power density of $120 \mathrm{~mW} \cdot \mathrm{cm}^{-2}$ which is about $50 \%$ higher than that of pristine Nafion membrane under identical operating conditions. The high proton conductivity and low methanol permeability are responsible for the improvement in overall cell performance. Even though the composite membrane with $1.25 \mathrm{wt}$. $\% \mathrm{CeO}_{2}$ has a lower methanol permeability, it exhibits a lower peak power density compared to Nafion- $\mathrm{CeO}_{2}(1 \mathrm{wt}$. \%) mainly due to its lower proton conductivity behaviour. Stability of the pristine Nafion and Nafion- $\mathrm{CeO}_{2}(1 \mathrm{wt}$. \%) composite membrane was evaluated in DMFC under OCV condition at $70{ }^{\circ} \mathrm{C}$ for $50 \mathrm{~h}$ as shown in Figure $7 \mathrm{~b}$. After $50 \mathrm{~h}$ of test, Nafion- $\mathrm{CeO}_{2}(1 \mathrm{wt}$ \%) composite membrane showed improved stability compared to pristine Nafion under identical operating conditions and is exclusively credited to the presence and interaction of nanofiller materials with the Nafion matrix.

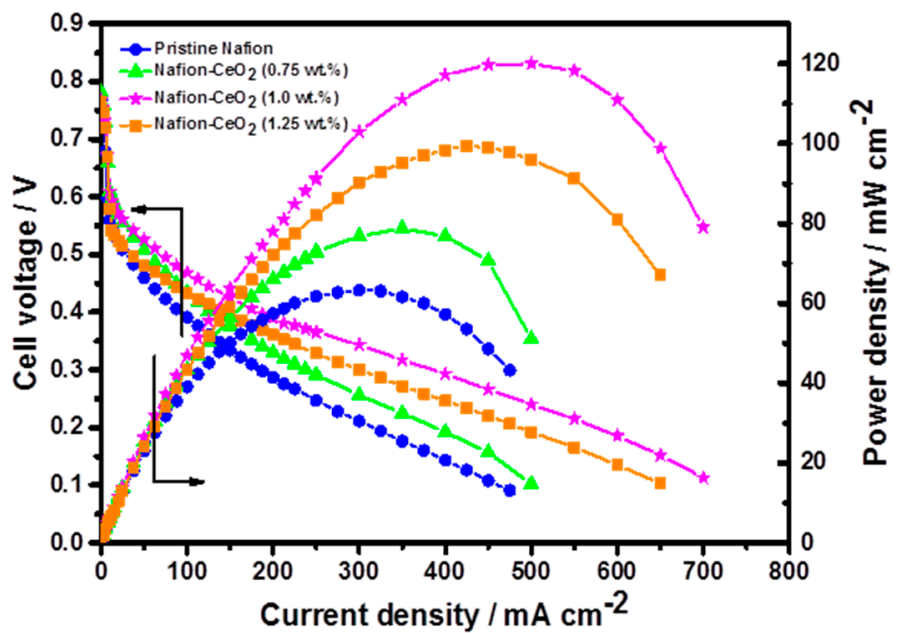

(a)

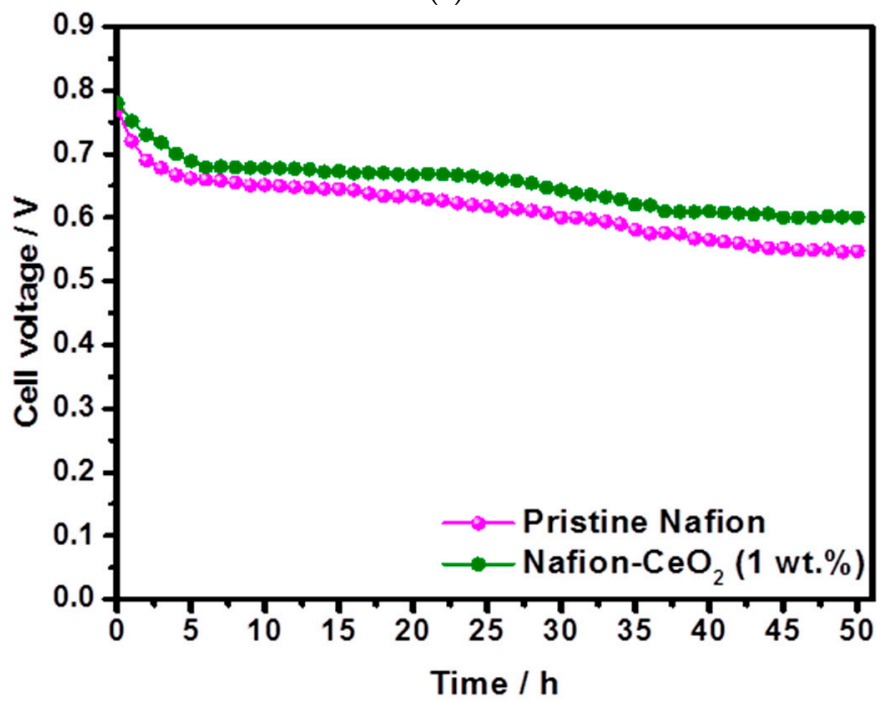

(b)

Figure 7. (a) DMFC performances of pristine Nafion and Nafion- $\mathrm{CeO}_{2}$ composite membrane at $70{ }^{\circ} \mathrm{C}$ under ambient pressure; (b) Stability test of the pristine Nafion and $\mathrm{Nafion}-\mathrm{CeO}_{2}(1 \mathrm{wt}$. \%) membranes for $50 \mathrm{~h}$ under OCV condition.

\section{Conclusions}

In this study, we have developed a novel Nafion composite membrane by incorporating $\mathrm{CeO}_{2}$ nanoparticles for application in DMFCs. The composite membrane showed improved proton conductivity with low methanol permeability as a result of effective interaction of nanosized $\mathrm{CeO}_{2}$ with the polymer matrix. As a result, the optimized composite membrane (Nafion- $\mathrm{CeO}_{2}(1 \mathrm{wt}$. \%) 
delivered a peak power density of $120 \mathrm{~mW} \cdot \mathrm{cm}^{-2}$ which is about $50 \%$ higher than that of a pristine Nafion membrane. These results established that the $\mathrm{Nafion}-\mathrm{CeO}_{2}$ composite membranes developed in this study area promising candidate as high performing polymer electrolyte membranes for DMFC applications.

Acknowledgments: We thank CSIR, New Delhi, for financial support through HYDEN (CSC-0122). We thank V. V. Giridhar, Scientist-in-Charge, CECRI Madras unit, and Vijayamohanan K. Pillai, Director, CECRI, Karaikudi, for their constant encouragement and support.

Author Contributions: Parthiban Velayutham and Akhila K. Sahu conceived and designed the experiments; Parthiban Velayutham performed the experiments. All the authors analyzed the data and wrote the paper.

Conflicts of Interest: The authors declare no conflict of interest.

\section{References}

1. Lufrano, F.; Baglio, V.; Di Blasi, O.; Staiti, P.; Antonucci, V.; Arico, A.S. Design of efficient methanol impermeable membranes for fuel cell applications. Phys. Chem. Chem. Phys. 2012, 14, 2718-2726. [CrossRef] [PubMed]

2. Sahu, A.K.; Bhat, S.D.; Pitchumani, S.; Sridhar, P.; Vimalan, V.; George, C.; Chandrakumar, N.; Shukla, A.K. Novel organic-inorganic composite polymer-electrolyte membranes for DMFCs. J. Membr. Sci. 2009, 345, 305-314. [CrossRef]

3. Meenakshi, S.; Sahu, A.K.; Bhat, S.D.; Sridhar, P.; Pitchumani, S.; Shukla, A.K. Mesostructuredaluminosilicate-Nafion hybrid membranes for direct methanol fuel cells. Electrochim. Acta 2013, 89, 35-44. [CrossRef]

4. Dutta, K.; Das, S.; Kundu, P.P. Partially sulfonated polyaniline induced high ion-exchange capacity and selectivity of Nafion membrane for application in direct methanol fuel cells. J. Membr. Sci. 2015, 473, 94-101. [CrossRef]

5. Cui, Y.; Baker, A.P.; Xu, X.; Xiang, Y.; Wang, L.; Lavorgna, M.; Wu, J. Enhancement of Nafion based membranes for direct methanol fuel cell applications through the inclusion of ammonium- $X$ zeolite fillers. J. Power Sources 2015, 294, 369-376. [CrossRef]

6. Li, J.; Fan, K.; Cai, W.; Ma, L.; Xu, G.; Xu, S.; Ma, L.; Cheng, H. An in-situ nano-scale swelling-filling strategy to improve overall performance of Nafion membrane for direct methanol fuel cell application. J. Power Sources 2016, 332, 37-41. [CrossRef]

7. Rodgers, M.P.; Shi, Z.; Holdcroft, S. Ex situ Characterisation of Composite Nafion Membranes Containing Zirconium Hydrogen Phosphate. Fuel Cells 2009, 9, 534-546. [CrossRef]

8. Chen, L.-C.; Yu, T.L.; Lin, H.-L.; Yeh, S.-H. Nafion/PTFE and zirconium phosphate modified Nafion/PTFE composite membranes for direct methanol fuel cells. J. Membr. Sci. 2008, 307, 10-20. [CrossRef]

9. Chien, H.-C.; Tsai, L.-D.; Huang, C.-P.; Kang, C.-Y.; Lin, J.-N.; Chang, F.-C. Sulfonated graphene oxide/Nafion composite membranes for high-performance direct methanol fuel cells. Int. J. Hydrog. Energy 2013, 38, 13792-13801. [CrossRef]

10. Yoonoo, C.; Dawson, C.P.; Roberts, E.P.L.; Holmes, S.M. Nafion ${ }^{\circledR} /$ mordenite composite membranes for improved direct methanol fuel cell performance. J. Membr. Sci. 2011, 369, 367-374. [CrossRef]

11. Parthiban, V.; Akula, S.; Peera, S.G.; Islam, N.; Sahu, A.K. Proton Conducting Nafion-Sulfonated Graphene Hybrid Membranes for Direct Methanol Fuel Cells with Reduced Methanol Crossover. Energy Fuels 2016, 30 , 725-734. [CrossRef]

12. Baglio, V.; Blasi, A.D.; Aricò, A.S.; Antonucci, V.; Antonucci, P.L.; Trakanprapai, C.; Esposito, V.; Licoccia, S.; Traversa, E. Composite Mesoporous Titania-Nafion Based Membranes for Direct Methanol Fuel Cell Operation at High Temperature. J. Electrochem. Soc. 2005, 152, A1373-A1377. [CrossRef]

13. Zhengbang, W.; Haolin, T.; Mu, P. Self-assembly of durable Nafion/ $/ \mathrm{TiO}_{2}$ nanowire electrolyte membranes for elevated-temperature PEM fuel cells. J. Membr. Sci. 2011, 369, 250-257. [CrossRef]

14. Zhang, Y.W.; Cai, W.W.; Si, F.Z.; Ge, J.J.; Liang, L.; Liu, C.P.; Xing, W. A modified Nafion membrane with extremely low methanol permeability via surface coating of sulfonated organic silica. Chem. Commun. 2012, 48, 2870-2872. [CrossRef] [PubMed] 
15. Sahu, A.K.; Meenakshi, S.; Bhat, S.D.; Shahid, A.; Sridhar, P.; Pitchumani, S.; Shukla, A.K. Meso-Structured Silica-Nafion Hybrid Membranes for Direct Methanol Fuel Cells. J. Electrochem. Soc. 2012, 159, F702-F710. [CrossRef]

16. Zhao, W.; Haolin, T.; Huijie, Z.; Ming, L.; Rui, C.; Pan, X.; Mu, P. Synthesis of Nafion/CeO 2 hybrid for chemically durable proton exchange membrane of fuel cell. J. Membr. Sci. 2012, 421, 201-210.

17. Lavorgna, M.; Gilbert, M.; Mascia, L.; Mensitieri, G.; Scherillo, G.; Ercolano, G. Hybridization of Nafion membranes with an acid functionalisedpolysiloxane: Effect of morphology on water sorption and proton conductivity. J. Membr. Sci. 2009, 330, 214-226. [CrossRef]

18. Trogadas, P.; Parrondo, J.; Ramani, V. Degradation Mitigation in Polymer Electrolyte Membranes Using Cerium Oxide as a Regenerative Free-Radical Scavenger. Electrochem. Solid State Lett. 2008, 11, B113-B116. [CrossRef]

19. Weissbach, T.; Peckham, T.J.; Holdcroft, S. $\mathrm{CeO}_{2}, \mathrm{ZrO}_{2}$ and $\mathrm{YSZ}$ as mitigating additives against degradation of proton exchange membranes by free radicals. J. Membr. Sci. 2016, 498, 94-104. [CrossRef]

20. Sahu, A.K.; Ketpang, K.; Shanmugam, S.; Kwon, O.; Lee, S.; Kim, H. Sulfonated Graphene-Nafion Composite Membranes for Polymer Electrolyte Fuel cells Operating under reduced relative Humidity. J. Phys. Chem. C 2016, 120, 15855-15866. [CrossRef]

21. Sasikala, S.; Selvaganesh, S.V.; Sahu, A.K.; Carbone, A.; Passalacqua, E. Block co-polymer templated mesoporous carbon-Nafion hybrid membranes for polymer electrolyte fuel cells under relative humidity. J. Membr. Sci. 2016, 499, 503-514. [CrossRef]

22. Xu, X.; Wang, H.; Lu, S.; Peng, S.; Xiang, Y. A Phosphotungstic Acid Self-Anchored Hybrid Proton Exchange Membrane for Direct Methanol Fuel Cells. RSC Adv. 2016, 6, 43049-43055. [CrossRef]

23. David, M.; Araba, M.; Guinneton, F.; Flahaut, E.; Bakiz, B.; Nowakowski, P.; Gavarri, J.R. Electrical properties and reactivity under air-CO flows of composite systems based on ceria coated carbon nanotubes. Chem. Eng. J. 2011, 171, 272-278. [CrossRef]

24. Veranitisagul, C.; Kaewvilai, A.; Sangngern, S.; Wattanathana, W.; Suramitr, S.; Koonsaeng, N.; Laobuthee, A. Novel Recovery of Nano-Structured Ceria $\left(\mathrm{CeO}_{2}\right)$ from Ce(III)-Benzoxazine Dimer Complexes via Thermal Decomposition. Int. J. Mol. Sci. 2011, 12, 4365-4377. [CrossRef] [PubMed]

25. Devrim, Y.; Erkan, S.; Bac, N.; Eroglu, I. Improvement of PEMFC performance with Nafion/inorganic nanocomposite membrane electrode assembly prepared by ultrasonic coating technique. Int. J. Hydrog. Energy 2012, 37, 16748-16758. [CrossRef]

26. Jia, W.; Feng, K.; Tang, B.; Wu, P. $\beta$-Cyclodextrin modified silica nanoparticles for Nafion based proton exchange membranes with significantly enhanced transport properties. J. Mater. Chem. A 2015, 3, 15607-15615. [CrossRef]

27. Beydaghi, H.; Javanbakht, M.; Bagheri, A.; Salarizadeh, P.; Ghafarian-Zahmatkesh, H.; Kashefi, S.; Kowsari, E. Novel nanocomposite membranes based on blended sulfonated poly(ether ether ketone)/poly(vinyl alcohol) containing sulfonated graphene oxide $/ \mathrm{Fe}_{3} \mathrm{O}_{4}$ nanosheets for DMFC applications. RSC Adv. 2015, 5, 74054-74064. [CrossRef]

28. Lavorgna, M.; Sansone, L.; Scherillo, G.; Gu, R.; Baker, A.P. Transport Properties of Zeolite Na-X-NafionMembranes: Effect of Zeolite Loadings and Particle Size. Fuel Cells 2011, 11, 801-813. [CrossRef]

29. Jalani, N.H.; Dunn, K.; Datta, R. Synthesis and characterization of Nafion ${ }^{\circledR}-\mathrm{MO}_{2}(\mathrm{M}=\mathrm{Zr}, \mathrm{Si}, \mathrm{Ti})$ nanocomposite membranes for higher temperature PEM fuel cells. Electrochim. Acta 2005, 51, 553-560. [CrossRef]

30. Wang, Y.; Han, G.; Tian, Z.; Wang, M.; Lia, J.; Wang, X. Nafion ${ }^{\circledR} / \mathrm{SiO}_{2} / \mathrm{m}-\mathrm{BOT}$ composite membranes for improved direct methanol fuel cell performance. RSC Adv. 2014, 4, 47129-47135. [CrossRef]

(C) 2017 by the authors. Licensee MDPI, Basel, Switzerland. This article is an open access article distributed under the terms and conditions of the Creative Commons Attribution (CC BY) license (http:/ / creativecommons.org/licenses/by/4.0/). 